\title{
Wittgenstein on Metaphor
}

\author{
Diogo de França Gurgel ${ }^{\star}$
}

\begin{abstract}
In this work, I examine Wittgenstein's possible contributions to an elucidation of the grammatical status of certain metaphors - often found in theoretical and speculative texts - which resist an approach based on the assumption of a clear split between the fields of pragmatics and semantics. I take as examples of works that depart from this assumption Elizabeth Camp's Contextualism, Metaphor and What is said (which explores the lines suggested by Paul Grice), and John Searle's Expression and Meaning. Both rely on a distinction between speaker's meaning (utterance meaning) and sentence meaning to explain the nature of metaphor. They assume that the very metaphorical operation involves meaning something instead of saying something. But it is anything but obvious that, when we consider, e.g., the following metaphor of Philosophical Investigations: "A picture held us prisoners" ( $§ 115)$, we can assume that we are facing a non-descriptive use of language. I argue that Wittgenstein himself can provide us with tools to examine a possible descriptive function of this kind of sentence when he develops his grammatical research methods which: a) are not focused on the linguistic dimension of a sentence but on the linguistic dimension of discourse; b) bring up the issue of language learning; c) lead us to ask if certain metaphors could not work as modifiers of convictions, i.e., if they could not act directly on what Wittgenstein once called Weltbild.
\end{abstract}

Keywords: Metaphor. Wittgenstein. Weltbild. Saying. Meaning.

\section{Introduction}

Think about all the things we name "metaphors". Carefully consider the differences between metaphorical sentences like "John is a pig" and "Argument is war" - could they both be called "abbreviated similes"? And what about the differences between "Juliet is the sun" and "No man is an island"? - Do they both deserve the label of blatant falsehood or the label of logical absurdity? I'm guessing your answer is "no". And the same response applies if someone claims that "Sally is a block of ice" and "He will eat me alive" are defective predications in the same way. Furthermore: if we can easily find a paraphrase for "He was burned up" - as Davidson once noted (DAVIDSON, 1978, p.38) - the same does

\footnotetext{
* Universidade Federal Fluminense - Department of Philosophy.
} 
not apply (is not valid) to the philosophical metaphor "By ideas I mean the faint images of these [impressions] (...)" (HUME, 2000, I, I, I, p. 7).

In this paper, I will focus on a specific kind of metaphor, whose fundamental notes could not be applied to all of the other kinds of metaphor. The metaphors I have in mind are: a) not paraphrasable; b) not based on similarities; c) of unavoidable use. In order to ensure the clarity of my exposition, I will also restrict myself to the in praesentia cases of their occurrence, in which their form " $\mathrm{S}$ is $\mathrm{P}$ " becomes explicit. ${ }^{1}$ When I affirm that this kind of metaphor is not paraphrasable, I affirm that one could not find a predicate $\mathrm{R}$, literal, that could sufficiently replace $\mathrm{P}$, and I also affirm that the comparative conjunctions "as" and "like" could not be added to the original sentence without mitigating the force of the assertion. Regarding the characteristic of not being based on similarities, I adopt as mine the words of such theorists of metaphor as Max Black and John Searle: everything is similar to everything in some aspect. Similarity is too vague a predicate and one can find a safer track saying that "the metaphor creates similarity" (BLACK, 2011, p.72), instead of saying the opposite. With respect to the metaphors I am focusing on, as we shall see, the establishment of similarities between the terms appears to be an inglorious task. And concerning the unavoidable use of certain metaphors, what I have in mind are especially the occurrence of metaphors in philosophical texts and theoretical texts in general. In texts on the philosophy of language, for example, one good opportunity for the proliferation of metaphors arises when philosophers find themselves required to provide explanations of the language-world relation. ${ }^{2}$ Another argumentative configuration in which the flourish of metaphors occurs is when we want to describe and to define the nature of our mental faculties. For instance, we could remember Descartes' claim that "Intuition is a natural light". ${ }^{3}$ But to keep in line with the purpose of this event, I will recall a very strong metaphor by one of the fathers of analytic philosophy. At

1 I employ the Aristotelian form in order to emphasize the copular verb and to formulate a dialogue with a group of theorists that examine metaphors through this approach.

2 According to Clive Cazeaux in Metaphor and Continental Philosophy, "explanations of how knowledge 'fits' the world are invariably metaphorical, for example, talk of knowledge mirroring the world, knowledge as a construction, correspondence and coherence theories of truth, receiving sensory impressions or sense-data." (CAZEAUX, 2007, p.134)

3 The ontological compromise seems to be great when Descartes employs "natural light" e "faculty of knowledge given to us by God" as synonyms (DESCARTES, 2002, 1, XXX; DESCARTES, 1930, III, 12, pp.86-87). The light metaphor that was provided by nature is systematically coherent with a worldview in which the truthful God appears as creator. Note that the same light metaphor is also used in order to talk about God in person: "to adore the incomparable beauty of that immense light" (DESCARTES, 1930, III, 41, p.98). 
the end of "On Concept and Object", Frege makes clear that his uses of terms like "complete" and "unsaturated" are not casual and that, at this point of his argument, he cannot avoid a certain "inadequacy of the linguistic expression". Frege demarcates this inevitability of the inadequate expression calling it "bildlicher Ausdruck" (figurative expression) (FREGE, 1960, p. 126-127). It is noteworthy that Wittgenstein has felt compelled to do the same in the so-called second part of Philosophische Untersuchungen, when he was trying to trace a distinction between similes, mere pictures (devices whose use we can choose) and another kind of shifted use of terms. There again we find the expression "bildlicher Ausdruck" (WITTGENSTEIN, 2009, part II, iv, 26). And If we are going to discuss scientific texts, the unavoidable metaphors are also frequent. How could William Harvey's description of the human circulatory system succeed without the metaphor "Heart is a hydraulic pump"?

These examples are cases of concept definitions, which is on purpose. The term which fulfills the subject position is a general term of the kind of in praesentia metaphors I am considering. I want to show that these metaphors have the form of assertions and that they are assertions in fact, when performing their task of defining concepts through the transgression of the current rules of sign usage. Is it not the case that we are able to discuss their truth value? Is it not what Aristotle did when he was challenging Plato on the employment of the word "participation" (méthexis) with the aim of metaphysical elucidations? These precursors asked each other: Do the noticeable things participate in the Ideas, or not?

Following this line of thinking, I ask you to examine the philosophers' use of metaphors of this kind. Above all, I invite you to consider the way Wittgenstein put them to work. In the Blue Book, Wittgenstein declares himself an inventor of new notations, claiming that it is a philosopher's task to find analogies between the uses of signs, so that these analogies can break the spell of usage of signs we are familiar with (WITTGENSTEIN, 1969, p. 23). And what can a metaphor do? What services can it provide us? I think we must be perplexed when facing the great number of works in the field of philosophy of language that depend on a distinction between the literal meaning and the figurative meaning, yet ignore the following alternative: Could it not be the case that certain metaphors were working on our deepest convictions, that is, on that ground that Wittgenstein once called our "world-picture" (Weltbild)? And we must keep in mind that a world-picture, as Wittgenstein understands it, is a shared system of convictions expressible by 
propositions whose truth is indubitable in the linguistic practices in which they occur. If this is the case (and, at first glance, nothing prevents it), and if we assume that what is claimed in On Certainty, that is, what counts as descriptions of facts is conditioned by a world-picture (WITTGENSTEIN, 1972, § 94 and $\S 103$ ), this would imply that we are committed to the existence of metaphors that are able to operate on indubitably descriptive propositions. And here I mean grammatical propositions that establish the conditions of what counts as fact descriptions in every single language-game.

However, in order to work on this level and in this way, metaphor should be a re-categorization resource. ${ }^{4}$ But how could we examine this possibility, if it is assumed beforehand that metaphor has nothing to do with saying something?

Moreover, we must not forget that this position was taken by important contemporary philosophers. Donald Davidson is radical, affirming that metaphors have no propositional nature. Searle is more moderate, conferring meaning to metaphors, but placing them on the level of the speaker's meaning (or utterance meaning), side by side with communicational resources, such as irony and indirect speech acts. Anyone who takes this perspective works with the idea that there is a clear distinction between what is actually said and some aspects of language that belong to a pragmatic order (wherever he/she connects this last order with the notions of utterance meaning, illocutionary force, conversational maxim or something similar). Adopting this perspective will always bring us back to the trichotomy established by Charles Morris in his Foundations of a Theory of Signs: syntax, semantics and pragmatics would clearly represent different matters. ${ }^{5}$

In this work, I defend the thesis that certain metaphors actually say something, and that they do it without failing to act in ways frequently labeled as pragmatic. I maintain that they occur in the form of sentences, whose study involves attempting to use and the conditions of use of signs. In other words, I see certain metaphors that are border cases between the semantic domain and pragmatic domain, as defined by Morris. I also defend that their modes of employment can only be properly examined if we depart from a conception of language that contemplates the fact that what counts as descriptions of facts changes in accordance with

4 I assume here that no metaphor, while a metaphor, can be taken as an expression of peacefully accepted conviction (in Wittgensteinian terminology, grammatical proposition), but that some metaphor can reveal itself as a resource of alteration of categorical convictions starting with the presentation of alternative categorizations.

5 In a general way, Morris' idea is that semantics studies the relationship between the sign and the thing to which it applies, while pragmatics studies the relationship between the sign and its interpreters. 
the different linguistic practices we are in. And that, for this reason, it is not possible to definitively determine literalness, leaving us with the distinction between canonical (current) and non-canonical uses, according to their stronger or weaker assertoric commitment. This approach, as I understand it, requires the consideration of the contrasts between distinct normative systems as well as of the mechanisms of shifting through these systems, which is precisely where I hope to find what we are looking for. As can be seen, I propose a conception of metaphor that simultaneously transgresses the binomial literal $x$ figurative and the binomial semantics x pragmatics. I will make John Searle my interlocutor by considering him one of the most accute and reasonable of the authors who deny that metaphors could be taken as a unique way of saying something literally.

First, I will give a short exposition of the conception of metaphor developed by Searle regarding Expression and Meaning. The philosopher adopts a distinction between sentence meaning and speaker's meaning as a fundamental procedure in the chapter reserved for the subject of metaphor. This distinction is pervasive throughout all his arguments, which include strong blows struck against the substitution and the interaction views of metaphor. The key moment of the text is when Searle presents the three steps that constitute our strategy of metaphor interpretation. They are as follows: 1) detection of utterance defection; 2) computation of $\mathrm{R}$ values - given that $\mathrm{R}$ is the literal predicate that presents the same conditions of truth as $\mathrm{P}$; 3 ) identification of the value intended by $\mathrm{R}$ within the values computed in the previous step - this identification can be made given as $\mathrm{S}$ and its compatibility with the terms that function as P. In the second step, the task is to clarify the pragmatic principles that would be acting in such a way as to comprehend the metaphor. This means a philosophical effort with respect to the establishment of the maxims or commands that could guide the receiver who seeks a non-employed but intended predicate $\mathrm{R}$ when he/she faces a metaphorical sentence in the form " $\mathrm{S}$ is $\mathrm{P}$ ".

Searle's work, we must recognize, has the following merits: it defends the existence of metaphorical meaning, it attacks the traditional notion that similarity is the fundamental criterion of the composition and comprehension of metaphors, it considers metaphor on the level of the sentence as a whole and it assumes 
that metaphor's peculiar way of working shall not be overlooked concerning its cognitive importance. This is a very respectable list of achievements if we recall that a few decades before (at a time when the seminal works of Richards and Black were still unpublished) the traditional (and weak) idea that metaphor is merely an abbreviated simile was still the predominant idea, and if we recall that any study of metaphor was bound to be taken as a study of discursive ornament.

Nevertheless, the distinction between sentence meaning and speaker's meaning leads Searle to an obstruction of an investigation of re-categorization through metaphors and leads him to ask if metaphors could not be declarative sentences actually committed to the presentation of something factual, working as resources of semantic bargaining.

In Searle's conception, the sentence meaning is nothing but the literal meaning. Moreover, "literal" is not merely an adjective for the current, canonic use, but it applies also to the describing use, I mean, that use which involves the analyses of conditions of truth. Searle maintains that a literal paraphrase is always possible with respect to saving a metaphor's conditions of truth. I cannot deny that we can build paraphrases of many sentences we commonly call "metaphorical", but I must not take for granted that everything we can call "metaphor" works in the same way.

Thus, it is necessary to denounce the problems with this approach. I believe that the worst of these problems is that Searle focuses too much on the relation between $\mathrm{P}$ and $\mathrm{R}$, and does not consider properly what happens when we have $\mathrm{P}$, and consequently, $\mathrm{S}$ as a reason for dispute. ${ }^{6}$ At this point, he took a step back in comparison to what Richards and Black reported. The philosopher was unable to investigate whether or not a metaphorical definition, as an assertion, would in fact require a predicate term $\mathrm{R}$. It is not a readily objectionable hypothesis that defends that some metaphorical sentences seem to be dueling with our linguistic habits for the meaning of the terms that occupy $\mathrm{P}$ and S positions. I argue that Searle cannot examine properly this possibility insofar as he lacks an agonistic view of language.

6 Searle bases himself upon the presupposition that interpreting a metaphor involves finding an R, as can be seen in the following passage: "In order to understand the metaphorical utterance, that here requires something more than his knowledge of the language, his awareness of the conditions of the utterance, and background assumptions that he shares with the speaker. He must have some other principals, or some other factual information, or some combination of principals and information that enables him to figure out that when the speaker says, 'S is P', he means ' $\mathrm{S}$ is R'. What is this extra element?" (SEARLE, 2011, p.256). 
In order to evaluate the impact of my criticism, I propose that we seek to apply the principles established by Searle to a metaphorical sentence that, as I comprehend it, is clearly committed to its assertoric form, demanding a re-categorization. Here is an example: "A picture held us captive" (WITTGENSTEIN, 2006, § 115) this is a sentence used by Wittgenstein in his Philosophische Untersuchungen. Let us use, for analysis, the implicit elementary proposition "Picture is prison", so that we expose its categorical form. It is necessary to bear in mind that this passage of the text connects with many others of the so-called second phase of Wittgenstein's career, and this reinforces his assumption that the philosophical task is constituted as a task of the dissolution of pictures that captures or bewitches our understanding. In the Untersuchungen, the philosopher claims that a certain picture (ein Bild) is still holding the logicians captive in much the same way as it had trapped himself (the author of the Tractatus), and comes to refer to it as the picture of the "crystalline purity of logic" (WITTGENSTEIN, 2006, § 107-108)

Before we seek to apply Searle's principles to Wittgenstein's metaphor, we need to take into account that the term that fulfills the position of subject in our metaphor is the term "picture" - that is to say: a term from our language of sensations or from our psychological vocabulary. And this fact brings us a wide range of difficulties. One of these is: how are we supposed to identify "salient, well known, and distinctive features" of S thing(s) (SEARLE, 2011, p. 275), that is, of things we can call "pictures", so that we could grasp the way in which $\mathrm{S}$ thing(s) might be like $\mathrm{P}$ things, that is, like things we call "prisons"? Here, we have two alternatives:

1) We assume that what is at stake are not publicly established features of pictures, but rather two introspective efforts. The first is an effort to determine the fundamental marks of our experiences with pictures, while the second is an effort to find the similarities between these and the distinctive notes of the current concept of prison that ensures the comprehensibility of Wittgenstein's metaphor. However, the idea that we could identify what happens in our minds

7 Wittgenstein admits having himself been a victim of bewitchment by the resources of our language, when he let himself be carried away by the conviction that logic, as the essence of thought, "presents an order: namely, the a priori order of the world; that is, the order of possibilities, which the world and thinking must have in common. But this order, it seems, must be utterly simple. It is prior to all experience, must run through all experience; no empirical cloudiness or uncertainty may attach to it. It must rather be of the purist crystal. But this crystal does not appear as an abstraction, but as something concrete, indeed, as the most concrete." (Tractatus Logico-Philosophicus, n. ${ }^{\circ}$ 5.5563.)"(WITTGENSTEIN, 2006, § 197). 
so that we can find a way of expressing it in a public language is intimately bound to a mentalist conception of meaning - and it is well known that Wittgenstein's remarks on private language strike incisive blows against mental process descriptions when they are supposed to be made by introspection, that is, in the first person and in the present tense (WITTGENSTEIN, 2006, § 243-316).

2) We assume that it is not necessary to find such distinctive features of $S$, because it is common knowledge that "Picture is R". Therefore, it is easy to take the metaphorical utterance "Picture is prison" as a tortuous way of provoking the remembrance that "Picture is R". This could be a good alternative if our pursuit of this $\mathrm{R}$ does not lead us hopelessly to other metaphors. Terms such as "barrier" or "obstacle" are terms that could be available to fulfill the R position in an alternative paraphrase of "Picture is prison", but, as can be seen, the sentences in the form " $\mathrm{S}$ is R", constructed from this replacement, would be paraphrases thought to be as metaphorical as that which we were supposed to elucidate.

Nevertheless, perhaps facing these difficulties in working with similarity in order to elucidate the metaphorical sentence we are examining, Searle would recommend a principle which does not demand an interpretation based on similarity, as he claims in his fourth principle:

Things which are $P$ are not $R$, nor are they like $R$ things, nor are they believed to be $R$; nonetheless it is a fact about our sensibility, whether culturally or naturally determined, that we just do perceive a connection, so that $\mathrm{P}$ is associated in our minds with $R$ properties. (SEARLE, 2011, p. 277)

Hence, seeking to understand how one could compute $\mathrm{R}$ values to interpret "Picture is prison", we should look for a certain connection promoted by our sensibility ("whether culturally or naturally determined") between prison and $\mathrm{R}$ properties. But this sounds so vague and unfounded (and smells like petitio principii) that I cannot avoid reproducing the reaction of another expert on metaphors, Mark Johnson, when he read this same passage from Searle's text: 
his final attempt to formulate a rule for certain types of metaphors is no explanation at all! (...) Saying that it just "is a fact about our sensibility" that we do make certain connections does not explain anything. When a literalist is forced to admit that certain metaphors are not based on any literal similarities between the source and target domains, then his literalism leaves him without resources to explain where the meaning comes from or how it is possible. (JOHNSON, 2010, p. 46)

Thus, Johnson claims that anyone who tries to avoid the difficulties exposed above, but at the same time wants to sustain Searle's literalist assumptions, will face a blatant lack of resources.

However, I must admit that the sixth pragmatic principle presented by Searle is promising. That principle advises us to look for $\mathrm{R}$ in cases where $\mathrm{P}$ and $\mathrm{R}$ are the same or similar in meaning, bearing in mind that one of them (usually P) is more restricted and does not apply literally to S (SEARLE, 2011, p.278). It allows us to conceive metaphors produced from differences of extension. But here a question emerges: Why does Searle presuppose an alternative predicate $\mathrm{R}$, since everything (all the matter) can be restricted to a conflict between different meanings of the same predicate $\mathrm{P}$ ? By introducing $\mathrm{R}$ as a literal predicate that is supposed to solve the metaphor, the philosopher creates a problem to the only principle of his that could explain the calculated transgression of grammar, that is, the strongest semantic innovation we can make using metaphors.

So far, this is my main point: we must not discard the possibility that one does not need paraphrases in the form of "S is $\mathrm{R}$ " to compose or to understand the kind of metaphor we are examining. What happens in them should not be simply taken as a term deviance. If we start to talk about a rule clash of the literal saying, Searle's principles do not shed light on our path.

Regarding the split between sentence meaning and speaker's meaning, we remain confined to a single system of rules of the literal saying and we therefore accept only certain predetermined assertoric conditions. Ultimately, we continue to deal with a language conception in which we are always sharing the same rules of literalness. It is noteworthy that this concept is full of assumptions that are frequently undertaken with an unclear mentalist view of literal meaning. In Searle's work, the device for examining the speaker's intention is a trace of this mentalist view, and it is used to distinguish sentence meaning and speaker's meaning. In Expression and Meaning, he declares that even the notion of literal 
meaning should be comprehended by means of an intentional criterion, that is, “conventional intentionality" (SEARLE, 2005, p. 131).

The problems involved in beginning with the split between sentence meaning and speaker's meaning (or from a split between what is said and what is implicated) in order to study metaphors become even more explicit in recent works. "Contextualism, Metaphor and What is Said", by Elizabeth Camp, is a good example of this. In her work, the author follows Paul Grice's suggestion, and takes metaphor as a case of flouting a conversational maxim - in this case, the maxim flouted is the so-called first maxim of Quality: "Do not say what you believe to be false." ${ }^{\prime 8}$ One of the arguments applied by Camp when defending her thesis is this: in metaphor as well as in implicature, sarcasm and malapropism, the interlocutors are not compelled to accept the figurative or indirect assertion as meaningful. ${ }^{9}$

But, by making this claim, she simply ignores countless situations in which a literalist challenge is actually a sign of linguistic incompetence. Let us consider, for example, a political dispute in which a speaker A utters, on the phone, the phrase "We are both on the same side" to a receiver B. It is hard to say that B's non-cooperation would be acceptable. If $\mathrm{B}$ assumes a radical and serious literalist posture, uttering in response something like "No, we are not on the same side. In fact, you are in one place and I am in another", we can say that he failed to detect the context of A's utterance and that, by consequence, he failed to comprehend the meaning of that utterance. Moreover, Camp's approach to metaphor is even more reductionist than Searle's approach. We have already seen that not all metaphors are blatant falsities. Let us remember, for example, metaphors such as "No man is an island".

Placing myself against Camp and Searle, I will ground my arguments on the linguistic evidence of a kind of metaphor that is non-paraphrasable and that seems

8 Paul Grice, in Studies in the Way of Words, takes metaphor as a case of violation of the first maxim of Quality, that is, "do not say that which you believe to be false". In a passage too brief for such a controversial theme, he says: "Examples like 'You are the cream in my coffee' characteristically involve categorical falsity, so the contradictory of what the speaker has made as if to say will, strictly speaking, be altruism; so it cannot be that such a speaker is trying to get across. The most likely supposition is that the speaker is attributing to his audience some feature or features in respect of which the audience resembles (more or less fancifully) the mentioned substance." (GRICE, 1991, p. 34)

9 That is, Benvolio can always reject Romeo's comparison between Juliet and the sun, claiming: "This is absurd!". But the reverse is not true: if Romeo were to insist upon the claim that Juliet is effectively the sun, a case of linguistic incompetence would be established and, perhaps, a mental illness would be observed. That is to say: If Romeo is in clear possession of his mental faculties and if he satisfactorily dominates the English language, he does not really believe that Juliet is the sun. 
to challenge the traditional notion of literalness. My aim is to disable a theory of metaphor based on the split between sentence meaning and speaker's meaning or - what amounts to the same - on the split between literal meaning and the flouting of a conversational maxim. I am conscious that the most natural objection to my claim would be: how to distinguish between a metaphor in the form " $\mathrm{S}$ is $\mathrm{P}$ " that means "S is P" and a simple and non-metaphorical sentence " $\mathrm{S}$ is P"? Therefore, developing my view in a manner that enables me to respond to this objection is precisely my next step.

II

Bearing in mind the difficulties presented above, which arise from the adoption of a conception of language grounded in the split between sentence meaning and speaker's meaning, I propose that we search for a path of investigation that is more appropriate for our aims. Our investigation must break from the problematic assumptions that prevent us from properly approaching the kind of metaphor with which we are concerned. Our task now seems to have better direction, given that we gather new elements for a more precise identification of this kind of metaphor.

Aristotle, the first philosopher to address the issue of metaphor, was also the first philosopher to note that the fundamental feature of metaphor is transference (epiphorá). But where could the traces of this transference be in a sentence that says " $\mathrm{S}$ is $\mathrm{P}$ " and means " $\mathrm{S}$ is $\mathrm{P}$ "? Here is a clue: it is the utterance itself that requires a transition between contexts by bearing terms of distinct normative systems. This implies presenting a whole linguistic practice in new terms.

For now, we remain in the realm of suggestion. In order to evaluate the plausibility of this suggestion, we should search for a conception of language that can encompass the examination of conflicts and trade-offs of meaning. Conducted in this manner, the investigation concerning the nature of metaphor leads us to see something that many theorists have neglected: "The main source of difficulty of communication is the difficulty to individuate the kind of context within which we are working" (PENCO, 2007, p. 579).

I argue that the conception of language we pursue is offered by Wittgenstein, the composer of the metaphor with which we have challenged Searle. The central positions of the so-called later Wittgenstein we know quite well. Let us take as the thread of our reasoning the idea that understanding a sign's meaning 
means understanding its uses in the language-games in which it occurs - without forgetting that this implies that studying semantics involves studying the learning process of the use of signs and that use is nothing but linguistic behavior. Thus, our investigation concerning the comprehension of a proposition $p$ should not be restricted to an investigation concerning what is said by this proposition Wittgenstein does not allow a split between the study of the semantic view of language and the study of the pragmatic view of language. In the concept of language elaborated by Wittgenstein after 1930, there is no room for a unified theory of literalness. In a relevant passage about this matter, he claims: "Remember how many different kinds of things are called 'description'." (WITTGENSTEIN, $2006, \S 24)$. There is also no room for mentalist semantics - and that is very explicit in the arguments against the possibility of a private language developed in Philosophische Untersuchungen. The border lines between two meanings of two concepts (or between two meanings of the same concept) are shown, in most cases, as diffuse, giving rise to different criteria of what is a competent use of the sign.

Another relevant methodological gain we have by examining metaphor from a Wittgensteinean conception of language consists of avoiding the unclear concept of context: due to excessive employment in the most diverse (and sometimes antagonistic) theories, the term "context" has become too vague. For this reason, it has become hard to find ways of preserving the concept related to it from uses committed to the idea that the semantic aspects of a sentence can be analyzed separately with respect to pragmatic and phonetic aspects. Furthermore, the determination of a language-game is considerably more accurate than the determination of a context realm. In the first case, we can focus on verbs of action, as does Wittgenstein in Philosophische Untersuchungen (WITTGENSTEIN, 2006, § 23). ${ }^{10}$ Furthermore, working with language-games requires the assumption that there is no criterion that pervades all the practices of language, which in itself excludes the possibility of working with a strong conception of literalness - In On Certainty, it is very clear: a rule that in one game is indubitable may be cause for dispute in another. (WITTGENSTEIN, 1972, § 96).

10 Here, I am working with a conception of language-game which is comprised of complex linguistic practices, such as telling a joke, or praying, and I am leaving aside other conceptions presented in the Philosophical Investigations. I am not considering, for example, invented language-games, which stand as objects of comparison. 
Since we work with the methods of grammatical investigation developed by Wittgenstein, we find a way of approaching the subject of metaphor from a discursive perspective - moving away from both the level of deviated word and from the level of inadequate predication, which is a decisive step. The metaphor appears as a move in a language-game (ein Zug im Sprachspiel) (WITTGENSTEIN, $2006, \S 22 ; \S 49)$ - preceded and followed by other moves, and may operate as a discursive (and conversational) device for changing the semantic levels.

The picture is complete when we take the interaction view developed by Richards and Black, inasmuch as it allows us to investigate our kind of metaphor: it is important to shed light on what they meant when they use expressions such as "transaction between contexts" (RICHARDS, 1936, p. 94) or "two thoughts of different things active together" (RICHARDS, 1936, p. 93) when discussing metaphors. ${ }^{11}$

If we consider that metaphors can be discursive devices capable of establishing transactions between language-games and that the concomitance of thoughts is nothing but the concomitance of two different normative systems in a same sentence, we have the following: a metaphor works as a device to transfer rules of sign usage from one normative system to another. The metaphorical move of language begins in one language-game and ends in another (or at another level of the same language-game). In this kind of metaphor, what occurs is something that Nelson Goodman once named "calculated category-mistake" (GOODMAN, 1976, p. 73). This calculus consists of: a speaker A presents a term $S$ in a familiar meaning to a receiver $\mathrm{B}$, but $\mathrm{A}$ applies to $\mathrm{S}$ a predicate $\mathrm{P}$ that is defective but not meaningless. $\mathrm{B}$ is able to solve the riddle when he/she sees the language-game in which the utterance is literal like the actual language-game. I am not, for sure, talking about being necessarily convinced by the metaphor, but I maintain that to grasp it is to understand that the system of rules in which it falls was already an underlying system (or game), even if we have ignored the fact previously.

Let us again take analyze the philosophical metaphor "Picture is prison" as a model in order to understand what is involved in metaphors of this kind. We must take into account some of Wittgenstein's remarks on language learning. In general, we do not learn the word's meaning from full definitions. We develop the habit of using a certain sign in a certain way from examples of use that never give us

11 "when we use a metaphor we have two thoughts of different things active together and supported by a single word, or phrase, whose meaning is a resultant of their interaction." (RICHARDS, 1936, p.93). 
a precise notion of this sign's extension. Vagueness reigns and leaves openings for semantic innovation. In this light, I defend that the recollection provided by metaphors is the recollection of alternative uses of signs, which are allowed in a few language-games (largely primitive games) and later disabled in most of our adult language-games. ${ }^{12}$ These alternative uses are non-canonical from the perspective of our most frequent linguistic practices, which is, in general, the perspective from which we judge. A certain extension of "prison" is recollected for the purpose of a re-categorization to be made in a language-game $\mathrm{X}$ (or this could be made between the levels $\mathrm{X}$ and $\mathrm{Y}$ of the same language-game). It is important to note that if this extension of the word is not proper, it is at least allowed in a language-game $\mathrm{Y}$, that is, allowed in the world-picture that underlies this game. This re-categorization relies on one grammatical proposition being transformed into another, which implies changing a whole set of empirical rules founded on this fundamental rule.

Hence, I claim that Wittgenstein makes use of categorical metaphors, which are devices used to act within a profound grammar, looking to disable metaphors like that of the crystalline purity of logic. ${ }^{13} \mathrm{We}$ can call these metaphors "figurative expressions" (bildliche Ausdrücke). The Wittgensteinean idea that philosophy is a fight against the bewitchment of our understanding by the means of our language is a good example of a figurative expression (WITTGENSTEIN, 2006, § 109). The kind of fight Wittgenstein has in mind calls up an entire army of figurative expressions like this - such is the case of "Language is game" and "Word is tool" - in order to shatter some judgments of philosophers and theorists in general about the contexts they believe they are in.

Therefore, to say that the philosopher calculates the category-mistake he/she intends to establish is to say that he/she finds the ways to fulfill a certain semantic gap which he/she is faced with. This is a procedure whose execution depends on

12 According to Wittgenstein, the apprentice takes part in a language-game; he/she is subjected to the verbal stimuli of this game and begins to mimic the most competent participants. But I would like to add to this idea: the apprentice is also taken to risk categorizations that seem consistent with the purposes of the game. As his/her vocabulary is still very limited and as he/she did not form the habits that allow the most competent participants to determine the signs of usage limits, he/she very often uses signs in extents that violate the rules of the game.

13 Metaphorical propositions should not be confused with grammatical propositions. Grammatical propositions, according to Wittgenstein, are propositions which occur in the form of empirical propositions, although they do not behave as such. They operate as foundations, as language-games testing rules. Since they are uttered, such propositions express beliefs, being undoubtedly true. Likewise, its denial does not reveal simple falsity, but rather nonsense. 
the following ability: perceiving which sets of rules may be disabled and finding the terms that, once re-signified, allow such disabling.

\section{Conclusion}

At the beginning of this text it was affirmed that certain metaphors can be seen as border cases between semantics and pragmatics. I hope that it is now clear what I meant by that. If on the one hand I assume that figurative expressions say something, presenting truth, value and a strong assertoric commitment, on the other hand I do not give up preserving the pragmatic aspects of these metaphors. The Wittgensteinean conception of language leads us to take every meaning as contextually dependent. But not only that. From this approach of discourse, one should not distinguish sentence meaning comprehension and speaker's meaning comprehension - Indeed, this lack of distinction is based on an even more fundamental assumption: grammatical rules are at the same time semantic rules and rules of behavior.

In this conclusion I am particularly concerned about clarifying what I call "figurative expression". It is, as I have already stated, a kind of metaphor that is non-paraphraseable, not based on similarity, of unavoidable use, and now we can add: a type of sentence which means precisely what it says. This last aspect deserves further elucidation. We can assign to it literalness, since by the term "literal" we mean definitions and descriptions of what is actual, factual and not the proper or current meaning of the terms. To be guided by a picture can actually stimulate certain actions and inhibit others: for example, a philosopher can exclude a whole vocabulary system from his/her theorization by believing in the picture of the crystalline purity of logic. A figurative expression does not have a literal paraphrase, because it is by itself a result of an effort to literally express the facts. Thus, I make reference to metaphors that present both catachresis features and semantic innovation features.

The study of the metaphorical transference working in figurative expressions that I have developed is focused on the techniques of sign usage that concern the way we use figurative expressions so that we can provide a displacement of meanings between language-games or between normative levels of language-games. In other words, it is an investigation that focuses on the conferral of relevance to a context that was already actual, wherein this actuality was ignored (or at least, was very unclear) due to a lack of an explicit, systematic order in our linguistic ways of discussing it. Following this path, I think we can develop a study of metaphor that maintains its 
characteristic of a grammatical investigation, avoiding certain traps of mentalism.

In this work, I did not thematise the striking problem of the reasons that lead a philosopher to resort to figurative expressions. However, I will at least leave a suggestion on the issue. I assume that elucidations of the ways in which words and expressions become concepts (or parts of them) and about the ways in which these concepts become problematic is an essential part of the philosophical task. Based on the good article by Gilbert Ryle called "Categories", I think that most of the conceptual elucidation made in philosophy is guided by the need for the dissolution of antinomies (RYLE, 1985, p. 33-34). If this is right, we can conclude that the offering of semantic innovations - or "intermediate links", “Zwischengliedern”, in a Wittgensteinean terminology (WITTGENSTEIN, § 122) - is part of the philosophical task of the dissolution of antinomies. Moreover, I am using "dissolving" instead of "solving" to preserve the idea that only science can solve speculative problems. In the realm of logical and grammatical certainties, one can only dissolve pseudo-problems. We are always, at this level, trying to find ways we can fail to see a specific problematic configuration.

\title{
Wittgenstein acerca da metáfora
}

\begin{abstract}
Resumo
Investigo, neste trabalho, as possíveis contribuições de Wittgenstein a uma elucidação do estatuto gramatical de certas metáforas - encontradas em larga escala em textos teóricos e especulativos - que resistem a uma abordagem que parta do pressuposto de uma clara cisão entre os campos da pragmática e da semântica. Tomo como exemplos de trabalhos que partem desse pressuposto o artigo "Contextualism, Metaphor and What is said", de Elizabeth Camp (texto que explora a linha sugerida por Paul Grice) e o livro Expression and Meaning, de John Searle. Ambos apoiam-se em uma distinção entre significado do falante (da elocução) e significado da sentença para explicar a natureza das metáforas, situando sua operação como algo da ordem do querer dizer ( to mean) e não da ordem do que é efetivamente dito em uma sentença. Não me parece nada evidente que, ao considerarmos a seguinte metáfora ocorrente nas Investigações Filosóficas: "Uma imagem nos mantinha presos" ( $\S 115)$, podemos assumir sem problemas que estamos diante de um uso figurado (não descritivo) da linguagem. Defendo que o próprio Wittgenstein pode nos fornecer ferramentas para examinarmos um
\end{abstract}


possível poder descritivo desse tipo de sentença ao desenvolver métodos de investigação gramatical que: a) não ficam centrados na dimensão linguística da sentença e sim na dimensão linguística do discurso; b) trazem à tona a questão do aprendizado da linguagem; c) permitem-nos perguntar se certas metáforas não poderiam atuar como modificadores de convicções, i.e., diretamente sobre o que Wittgenstein denomina Weltbild.

Palavras-chave: Metáfora. Wittgenstein. Weltbild. Dizer. Querer dizer.

\section{References}

BLACK, M. Metaphor. In: JOHNSON, M. (Org.) Philosophical Perspectives on Metaphor. Minneapolis: University of Minnesota Press, 2011. p. 63-82.

CAMP, E. Contextualism, Metaphor and What is Said. Mind \& Language, Oxford, v. 21, n. 3, p. 280-309, June, 2006.

CAZEAUX, C. Metaphor and Continental Philosophy: From Kant to Derrida. New York: Routledge, 2007.

DAVIDSON, D. What Metaphors Mean. Critical Inquiry, Chicago, v. 5, n. 1, Special Issue on Metaphor, p. 31-47, Autumn, 1978.

DESCARTES, R. Discours de la Méthode suivi des Méditations Métaphysiques. Paris: Ernest Flammarion Éditeur, 1930.

DESCARTES, R. Princípios da Filosofia.Translated by Guido Antônio de Almeida (Coord.). Rio de Janeiro: Editora UFRJ, 2002.

FREGE, G. On Concept and Object. In: Black M.; Geach, Peter (Transl). Translations from the Philosophical Writings of Gottlob Frege. Oxford: Basil Blackwell, 1960. p. 42-55.

GOODMAN, N. Languages of Art: An approach to a Theory of Symbols. Indianapolis: Hackett, 1976.

GRICE, P. Studies in the Ways of Words. London: Harvard, 1991.

HUME, D. A Treatise of Human Nature. New York: Oxford University Press, 2000 .

JOHNSON, M. Philosophy's debt to metaphor. In: Gibbs, R. W. Jr. (Org.). The Cambridge Handbook of Metaphor and Thought. New York: Cambridge University Press, 2010. p. 39-52.

MORRIS, C. Fundamentos da Teoria dos Signos. Translated by Milton José Pinto and Paulo Alcoforado. São Paulo: Edusp, 1976. 
PENCO, C. Idiolect and Context. In: AUXIER, R.E.; HAHN (Org.). The Philosophy of Michael Dummett. Chicago: Open Court, 2007. p. 267-590.

RICHARDS, I.A. The Philosophy of Rhetoric. Oxford: Oxford University Press, 1936.

RYLE, G. Categorias. Translated by Balthazar Barbosa Filho. In: Coleção Os Pensadores, 3. ed. São Paulo: Abril Cultural, 1985. p. 37-52.

SEARLE, J. Expression and Meaning: Studies in the Theory of Speech Acts. New York: Cambridge University Press, 2005.

SEARLE, J. Metaphor. In: JOHNSON, M. (Org.). Philosophical Perspectives on Metaphor. Minneapolis: University of Minnesota Press, 2011.- p. 248-285.

WITTGEnSTEIN, L. Tractatus Logico-Philosophicus; Tagebücher 19141916; Philosophische Untersuchungen. Frankfurt am Main: Suhrkamp, 2006. WITTGEnSteIn, L. The Blue and Brown Books. Oxford: Basil Blackwell, 1969.

WITTGENSTEIN, L. On Certainty. Translated by Denis Paul e G.E. Anscombe. New York: Harper \& Row, publishers, 1972.

Recebido em 01/04/2016.

Aceito em 05/07/2016. 